\title{
The effects of economic crisis on trust: Paradoxes for social capital theory
}

\author{
Jordi Caïs \\ University of Barcelona, Department of Sociology (jcais@ub.edu) \\ Diego Torrente \\ University of Barcelona, Department of Sociology (diego.torrente@ub.edu) \\ Catalina Bolancé \\ University of Barcelona, Department of Econometrics (bolance@ub.edu)
}

\begin{abstract}
The theory of social capital rarely takes economic variables into account. This article confirms that economic factors had greater explanatory power for social trust and trust in institutions during times of economic crisis, due mainly to increased economic polarization of the population. We use Spain as a case study to analyse the impact of a number of variables on social and institutional trust before and during the economic crisis. The economic crisis in Spain resulted in a paradox: a notable decline in trust in institutions, together with a surprising increase - rather than the expected decrease - in social trust. The data analysed here also highlight the possibility that the two types of trust did not track in a mutually supportive manner due to the emergence of Movimiento $15 \mathrm{M}$, which gave rise to the appearance of new political parties such as Podemos, on the extreme left of the electoral scale.
\end{abstract}

Keywords: Social trust, trust in institutions, economic crisis, political movements, social capital.

\section{The effects of economic crisis on trust}

The objective of this study is to analyse the different impacts that economic polarisation, generated by economic crisis, has on social trust and trust in institutions. In explaining levels of trust, the theory of social capital focuses more on social variables such as civic participation, satisfaction with democracy and the appearance of a critical citizenry, and less on the effect of economic variables. We hypothesise that, in addition to these social effects, increased economic 
polarisation in moments of economic crisis alters the foundations of social trust and trust in institutions.

Although social trust and trust in institutions are distinct variables, they are frequently considered to feed into each other, and to be mutually supportive (Putnam, 1993, 2000; Brehm and Rhan, 1997; Newton and Norris, 2000; Zmerli and Newton, 2008; Rothstein, 2011). In this study we seek to analyse how the two variables behaved in a context of economic recession. To date, explanations of social trust and trust in institutions have focused more on questions of civic participation (Putnam, 1993, 2000), on satisfaction with democracy (Zmerli and Newton, 2008), and on the presence of a critical citizenry (Norris, 2011), than on the economy. Our hypothesis, however, is that in moments of economic crisis, the relationship between the two types of trust is not mutually supportive for two key reasons. The first refers to the fact that economic polarisation profoundly changes the basis of social trust and trust in institutions. The second refers to the social response to the emergence of new leftist social and political movements that are highly critical of institutions, but that trust in the capacities of society. We aim to investigate whether these two factors - increased economic polarisation and the emergence of leftist movements - that emerged from the economic crisis contributed to the non-mutually supportive relationship between social trust and trust in institutions, contrary to the predictions of social capital theory.

To test both hypothesis we use the case of economic crisis in Spain to analyse the impact of a number of variables on social trust and trust in institutions before and during the economic crisis. Using data for Spain from the European Social Survey, 
we conduct structural equation modelling with five dependent variables. One of these variables is trust between individuals (social trust). To facilitate observations of differential effects, the other four variables are four different forms of trust in institutions: trust in Parliament, trust in political parties, trust in the legal system, and trust in the police. The model involves testing the effects of five economic variables and one political variable. The economic variables are: a person's satisfaction with the economy; whether they have economic difficulties or not; their principal source of income; the type of employment contract they hold; and whether or not they are unemployed. And, the political variable is: self-positioning on the political spectrum (from one to 10 , from left to right).

We compare these effects with the effects of two variables which, at the theoretical level, are considered to influence levels of trust: 1) satisfaction with democracy, 2) civic participation (whether a person has been part of a civic association in the past 12 months). We control for the effect of other socioeconomic variables. The model is replicated at two specific points in time: before the crisis (2004) and during the crisis (2013) to allow an assessment of any changes that may be attributed to the crisis.

The economic crisis had a more socioeconomically significant impact in Spain than in the majority of European Union (EU) countries. Spain's GDP per capita declined in line with other EU countries during the crisis: in 2006, GDP stood above the average for EU countries (105\%), but by 2013 it was already below the average, at 95\% (EUROSTAT, 2015). Public debt, which in 2007 stood at $36.1 \%$ of GDP, rose to $93.4 \%$ by 2013 (Bank of Spain, 2013). The impact of the crisis on 
labour markets was devastating. Unemployment, from $7.95 \%$ of the active population in 2007 , reached the historical high of $27.16 \%$ in 2013 , with youth unemployment (unemployed individuals aged less than 25 years) reaching $57.2 \%$ according to the national Labour Force Survey (2013). Such figures paint a picture of general deterioration in quality of life, corroborated by the fact that average household income in Spain fell from 29,634 euros per year in 2009 to 26,174 euros per year in 2013, according to the national Quality of Life Survey (Spanish Statistical Office, 2015). In addition, poverty and social exclusion increased at an alarming rate from the beginning of the crisis. In $2014,29.2 \%$ of the Spanish population found itself at risk of poverty or social exclusion, 2.3 million people more than in 2008 and exceeding the EU15 average by more than 6 percentage points (Intermon-Oxfam, 2016).

The economic crisis had three key effects at social and political levels: 1) a rapid increase in income inequalities given that the crisis affected the rich and the poor in very different ways; 2) the emergence of the $15 \mathrm{M}$ Movement (Movimiento 15M) in 2011, which gave rise to new political parties that identified as more left-leaning than traditional parties, with the most notable case being the We Can (Podemos) party, founded in 2014; and 3) a collapse in trust in institutions among Spanish citizens together with a surprising increase in social trust.

The rapid rise in income disparities in Spain during the crisis was particularly significant. Discounting Cyprus, of all OECD countries Spain saw the greatest increase in inequality as a result of the crisis: an increase almost 10 times greater than the European average, and 14 times more than increases in Greece 
(Intermon-Oxfam, 2016). Although the crisis affected the entire Spanish population, it did not do so equally, with the poorest losing significantly more than the richest. Between 2008 and 2011, the poorest $10 \%$ of society saw their annual incomes decrease by $42.4 \%$, while the richest $10 \%$ saw a decrease of just $5.6 \%$ in the same period. With this, Spain became the second-most economically unequal country in the EU, exceeded only by the United Kingdom, according to the Income Inequality Update (OECD, 2014).

The economic crisis in Spain also gave rise to public protests between 2011 and 2015. These protests became known as the 15M Movement (Movimiento 15M), or the movement of the Indignados (known in many international spheres as the "Spanish Revolution"). The protests gave voice to a wide range of political, economic and social claims that reflected the desire of participants for profound changes in the prevailing democratic and economic model of the time. From this social mobilization emerged new political parties that leaned further to the left of traditional parties. The most significant of these was We Can (Podemos), which was established in January 2014 and participated in the European elections of the same year, securing five Eurodeputies and becoming the fourth most voted for group. 1

\footnotetext{
${ }^{1}$ Following Parés, Ospina and Subirats in their book "Social Innovation and Democratic Leadership" published in 2017 at Edward Elgar, 15 M movement in Spain is a significant example of the urban protests that has multiplied at a global level such as Occupy Wall Street in the US and "the Arab Spring". These protests have been conceptualized as "Revolution 2.0". These mobilizations were linked to a proliferating series of eruptions of discontent in cities as diverse as Madrid, Barcelona, Athens, Lisbon, Rome, El Cairo, Istanbul, Sao Paulo, México, Honk Kong, Paris and New York. In the countries of Southern Europe the crisis was especially virulent, so these social movements remained firm, giving rise to political parties of the extreme left such as Podemos in Spain, Syriza in Greece, or the 5 Star Movement in Italy.
} 
Yet perhaps the most surprising effect of the 2008 crisis was that Spanish citizens' trust in democratic institutions decreased notably, while social trust, understood as trust in other individuals, not only did not decrease, but in fact increased. Table 1 compares social trust and trust in institutions among Spanish citizens in 2004, a year in which GDP growth in Spain was significant due to growth in the real estate sector and the mass arrival of immigrant workers in the construction and services sectors, and in 2012, during full economic crisis.

Table 1

People trusting in others and in institucions in 2004 and 2012 in Spain (In percentatges)

\begin{tabular}{|c|c|c|c|c|c|c|}
\hline \multirow{2}{*}{ Trust in: } & \multicolumn{2}{|c|}{$\begin{array}{c}\text { Trust } \\
\text { (Scale 6-10) }\end{array}$} & \multicolumn{2}{|c|}{$\begin{array}{l}\text { Not Trust } \\
\text { (Scale 0-4) }\end{array}$} & \multicolumn{2}{|c|}{$\begin{array}{c}\text { Neutral } \\
\text { (Scale 5) }\end{array}$} \\
\hline & 2004 & 2012 & 2004 & 2012 & 2004 & 2012 \\
\hline Other people & $39,6 \%$ & $44,3 \%$ & $34,8 \%$ & $31,2 \%$ & $25,6 \%$ & $24,5 \%$ \\
\hline Paralament & 42,9 & 21,1 & 29,8 & 61,5 & 27,3 & 17,4 \\
\hline Political parties & 20,0 & 7,1 & 57,4 & 84,7 & 22,6 & 8,2 \\
\hline Legal system & 37,5 & 24,9 & 41,5 & 59,5 & 21,0 & 15,6 \\
\hline Police & 59,0 & 59,0 & 21,2 & 23,8 & 19,8 & 17,2 \\
\hline
\end{tabular}

Source: European Social Survey, 2004 and 2013 waves.

Note: Interpersonal trust questions is: "Generally speaking, would you say that most people can be trusted, or that you can't be too careful in dealing with people?". Answers are placed in a score of 0 to 10 , where 0 means you can't be too careful and 10 means that most people can be trusted. Intitutional trust question is: "Please tell me on a score of 0-10 how much you personally trust each of the institutions I read out. 0 means you do not trust an institution at all, and 10 means you have complete trust". We recoded both variables 0 to 4 to not trust, 5 neutral, and 6 to 10 trust.

The data show that the percentage of people not trusting in Parliament doubled between 2004 and 2012, growing from almost 30\% to more than $60 \%$. Trust in political parties was already very low in 2004 , with more than $57 \%$ of people stating that they mistrusted political parties, but during the crisis it collapsed: 
almost $85 \%$ said they mistrusted political parties and only $7 \%$ stated that they trusted them. Citizens also lost trust in the legal system: before the crisis, $40 \%$ of people mistrusted the legal system, with this number rising to almost $60 \%$ during the crisis. The only institution that saw continued trust from citizens was the police. These changes coincided with harsh governmental economic adjustments and a rapid increase in poverty and inequality. Yet the clear collapse in trust in institutions was not mirrored by a collapse in social trust. Rather, social trust during the crisis increased by almost five percentage points: from nearly $40 \%$, the number of people stating that they trusted others rose to around $45 \%$. In theoretical terms, it is no surprise that the economic crisis led to decreases in trust in democratic institutions (Rothstein and Uslaner, 2005; Nannestad 2008; Zmerli and Castillo, 2015). However, what is surprising is that this decrease was not accompanied by a decrease in social trust.

\section{Theoretical framework}

Interpersonal exchanges and reciprocity are basic elements of social life and human behaviour. The very notion of society is inseparable from these, and from all types of relationships among people. However, in order to function, human relationships require a minimal level of trust. Social trust offers the cohesiveness necessary for producing meaningful social relationships. There is a consensus among scholars that trust is a necessary condition for a healthy economy, society and political life (Uslaner, 2002). However, there are a number of nuances in defining trust. 
Social trust can be defined as a belief that others will not cause one harm in a deliberate or conscious manner, if they can avoid it, and that they will consider one's interests as far as possible (Delhey and Newton, 2005). The assumption here is that people choose how they behave. Conversely, Luhmann (1979) conceives trust simply as a mechanism for reducing uncertainty and the complexity of the world today. For Yamagishi (2001), trust is a form of social intelligence that is contingent on people having mutual interests and certain characteristics. Cultural theories suggest that social values influence the degree to which individuals trust one another, although these effects are seen only in the medium and long-term. For example, Rahn and Transue (1998) revealed that the rapid growth of materialistic values among young North Americans in the 1970s and early 1980s reduced their level of trust in other people. Putnam (2000) also points to a decline in social trust in the United States and links this with a change in daily lifestyle, citing a lack of spare time, the incorporation of women into the labour market, increasing city size and individual anonymity, mobility facilitated by the mass use of cars and the influence of technology and communication media as factors. Individual and collective levels of optimism are also related to levels of trust (Uslaner 2002).

Social trust is distinct from trust in institutions (Putnam, 1993; Uslaner, 2002). Newton (1999) argues that social trust belongs to the private sphere and that it is a characteristic of personal relationships based on first hand experiences and knowledge. Conversely, trust in institutions belongs to the public and political spheres and it is established based on secondary sources, particularly mass 
communication media. According to Levi and Stoker (2000), trust in institutions depends on individuals' positive evaluations of the most relevant attributes making each institution worthy of trust, such as credibility, justice, competence, transparency and openness to different points of view. The quality of institutions and their operation affects levels of trust (Rothstein, 2011). Existing research, known as performance theories, propose that citizens' trust in institutions depends on their perceptions of how those institutions are performing. Lipset and Schneider (1987) highlight that levels of trust in institutions are primarily linked to the effect that institutional action has on the economic wellbeing of citizens. Other authors, such as Kramer (1983), posit that the successes and prestige of the State are also central in determining the level of trust that people have in democratic institutions. Newton and Norris (2000) equate trust in institutions and political trust given that they consider trust in institutions to be the key indicator of citizens' fundamental views of the political system. According to Montero, Zmerli and Newton (2008), political trust in an institution entails a belief that the institution will not act in an arbitrary or discriminatory manner that would be damaging for the interests of the people or the country, but that it will treat all citizens in an equal, fair and correct manner.

Although social trust and trust in institutions are two distinct concepts, in line with the theory of social capital, they tend to be viewed as related and as feeding into each other (Putnam, 1992, 2000; Brehm and Rhan, 1997; Newton and Norris, 2000; Zmerli and Newton, 2008; Rothstein, 2011). As Zmerli and Newton (2008) explain, social trust facilitates cooperation and reinforces behaviours that are beneficial to the general public interest. Trust between individuals promotes 
tolerance and empathy, increases interactions, and favours voluntary work and participation in associations (Hearn, 1997). In organizations, trust promotes a climate of cooperation, job satisfaction and increased productivity (Fukuyama 1995). In this sense, trust helps to build the institutional bases of civil society, upon which a stable, peaceful and efficient democracy can function. Zmerli and Newton (2008) also argue that democracy and good governance, in turn, reinforce the conditions that allow social trust and trust in institutions to develop, leading citizens to cooperate effectively both in the private and public spheres.

This relationship between social trust and trust in institutions is generally accepted at the theoretical level. However, in cases where empirical evidence is sought, the relationship appears more ambiguous. Although numerous studies demonstrate the existence of a clear and positive relationship between social trust and trust in institutions (Brehm and Rhan, 1997; Jagodzinski and Manabe, 2004; Zmerli and Newton, 2008), others suggest that the correlation between the two is weak or even negative (Newton, 1999; Newton and Norris, 2000, Uslaner, 2002; Sønderskov and Dinesen, 2016).

Within the theory of social capital, trust is more often explained using variables such as levels of civic participation, satisfaction with democracy, or a more pronounced critical citizenry, and less through economic variables. Some scholars posit that the existence of mature civil societies is a reflexion of, but also a condition for, the blossoming of social trust. Putnam (1993) points out that people learn civic virtues and learn to trust in the framework of their relationships, and particularly their voluntary relationships. Reciprocal exchanges produce greater 
trust and emotional attachment when they are spontaneous than when they are negotiated (Molm, Takahashi and Peterson, 2000). People with a richer social network tend to have greater trust in others than people who lead more isolated lives. However, a person's position in this network also matters. Individuals in more central positions in the network, particularly in the case of a dense network, express greater levels of trust than others (Buskens, 1998). Similarly, people who have succeeded in life tend to trust more or, at least, they are more inclined to due to their own personal experience (Delhey and Newton, 2005).

There is therefore an important relationship between civic participation and social trust, as described by Brehm and Rahn (1997). The same authors, however, also observe that civic participation is negatively related to trust in government (Brehm and Rahn, 1997). In this sense, although numerous studies agree that civic participation generates greater levels of social trust, the same is not necessarily true for trust in institutions: certain studies hold that civic participation reinforces trust in institutions (Rosenstone and Hansen, 1993; Leighley, 1996) while others state that the relationship is not significant (Newton, 1999, 2001; Newton and Norris, 2000).

In their 2008 study, Zmerli and Newton present robust and statistically significant correlations that confirm the relationship between levels of satisfaction with democracy and both social trust and trust in institutions. In previous work, the same authors argue that an individual's satisfaction with democracy is based on a set of perceptions - which tend to remain stable over time - of the capacity of a certain political system to resolve problems deemed important by the individual. 
Furthermore, the authors stress the need to distinguish satisfaction with democracy from political satisfaction, which consists of citizens' evaluations of the performance of authorities and their political results. Although citizens of advanced economies remain largely committed to democratic principles, they have gradually been losing trust in political institutions. For example, as a result of the EU's economic adjustment programme, citizens in crisis-hit countries appear to have become 'detached' from their democratic political system (Armingeon, Guthmann, and Weisstanner 2016). Nevertheless, in this regard, other studies stress the importance of institutional performance (Torcal 2014).

Despite the fact that the theory of social capital gives more weight to the variables of civic participation and levels of trust in democracy than it gives to socioeconomic conditions in explaining trust, there is robust evidence that trust is associated with economic equality and equality of opportunities (Delhey and Newton, 2005; Nannestad, 2008; Rothstein and Uslaner, 2005). Countries with significant inequalities suffer from limited trust in their institutions (Zmerli and Castillo, 2015). Various authors maintain that the increasingly unequal distribution of incomes and wealth is responsible for a general decrease in trust (Putnam, 1993; Fukuyama, 1995). As inequality increases, so does the social distance between people, leading them to believe that they have less in common and, in the medium term, resulting in the development of different cultures (Fairbrother and Martin, 2013). While trust is strengthened among the upwardly socially mobile, the opposite is true for those with little social mobility (Yaojun, Savage and Warde, 2008). At a more individual level, there is also evidence that situations of socioeconomic difficulty, such as unemployment, are associated with a reduction 
in trust (Iravany and Dindar, 2011). Therefore, there is a broad consensus in the literature regarding the importance of inequality, but the opposite is also true.

Bergh and Bjørnskov (2014), for example, find that low levels of social trust have a more direct impact on inequality and low economic development.

Following Parés, Ospina and Subirats (2017), after the 2008 financial collapse liberal-representative democracies conformed to a consensus based post-political paradigm in which there was no space for alternatives and dissensus. Dissidents were excluded from the political debate and politics was divided between: those with access to and control over resources, and who influenced public policies and produced dominant and hegemonic discourses, and those without resources or policy influences, who were marginalized. Nevertheless, the 2011 global uprisings brought hope for alternative forms of understanding and practicing what same authors, such as Mouffe (1992) had earlier named "radical democracy". Despite the fact that these urban political movements occurred in a wide variety of historical and geographical contexts, they spread a new way of conceiving of and engaging in a collective action (Della Porta 2015), new organizing practices and new forms of collective leadership characterized by networks (Cullen-Lester and Yammarino 2016).

In this context of distrust in the classic institutions, and the uprising of social practices that could be drivers of social change in political terms, extreme left parties, as it is the case of Podemos ("We can"), which promise egalitarian practices and new forms of leadership, have their chance to consolidate. As Blanco, Fleury and Subirats (2012) point out, in a face of a weak and delegitimized 
State, community responses focused on social transformation could emerge as new institutionalities redistributing resources and power in each community.

\section{Methodology}

The objectives and hypothesis of this study require the measurement of variation over time in the explanatory capacity of the various factors impacting social trust and trust in institutions (Fairbrother and Martin, 2013). We therefore use structural equation modelling to analyse the 'crisis effect' on social trust and trust in institutions in an integrated manner. The effect of the crisis is estimated by comparing two points in time. Specifically, we compare the years 2004 (before the crisis) and 2013 (during the crisis). The data are drawn from the second and sixth editions of the European Social Survey (ESS2 and ESS6). The sample size is 1663 (ESS2) and 1889 (ESS6) individuals over 15 years of age. The sampling method used is stratified two-stage probability sampling. Fieldwork was conducted between September 2004 and January 2005, and between January and May 2013, respectively.

The structural equation modelling consists of five dependent variables. The first is social trust, measured through the question "do you believe that you can trust in others?" The other four are variables that measure trust in political institutions (parliament, political parties, the legal system and the police). These five variables, measured on a scale of 0 to 10 , are dichotomised with 5 as the cut-off point. We note that the original variables cannot be analysed as a normal multivariate curve; 
as a result, the structural equation model can't be estimated using these as dependent variables. Furthermore, considering that we have ordinal dependent variables, if our aim is to analyse both: the individual and simultaneous behaviour, the available sample does not have sufficient information to represent the effects of the explanatory variables in each value of the scale. Therefore, although grouping the scale of 0 to 10 can be interpreted as a loss of information, it is necessary to do so to identify the effects of the explanatory variables in a multivariate model. Given that it's difficult to justify the many various alternatives, which are available when aggregating the original scale, we addressed this difficulty by simplifying the process and forming two groups -below 5 and equal to and above 5 . The selection of 5 as the cut-off point is based on the fact that in 2004 the means of the variables in the original scale are close to 5 and, although in 2012 these means had tended to decline, except for the trust in other people, we maintained the same cut-off point to have the same reference in both years.

Our explanatory variables consist of a number of variables linked to the economy: satisfaction with the economy, living with economic difficulties (or not), main source of income, and type of contract held/whether unemployed; and a variable that involves placing a person's political ideology on a scale (from left to right) in order to assess the effect of the Movimiento 15M's protests and its progressive drift towards the creation of political parties that are more left-leaning than Spain's traditional parties. We compare the effects of the economic and political variables with the effects of two variables to which the theory of social capital usually attributes the most influence on trust: satisfaction with democracy and the level of civic participation, measured by asking whether someone has participated in a 
civic organisation in the previous 12 months. Finally, we include control variables relating to some key socio-demographic variables such as gender, age, education level, extent of religiosity, place of birth (Spain or overseas), and political placement on the left-right axis. ${ }^{2}$

In this study, we analyse five indicators of trust. Let these indicators be $Y_{j}^{*}, j=$ $1, \ldots, 5$, five random, continuous variables whose values indicate the level of trust in j. Our objective is to estimate the following multivariate model, consisting of five regression equations linked through their random error terms:

$$
\begin{gathered}
Y_{1}^{*}=x^{\prime} \beta_{1}+\varepsilon_{1} \\
Y_{2}^{*}=x^{\prime} \beta_{2}+\varepsilon_{2} Y_{3}^{*}=x^{\prime} \beta_{3}+\varepsilon_{3} \\
Y_{4}^{*}=x^{\prime} \beta_{4}+\varepsilon_{4} Y_{5}^{*}=x^{\prime} \beta_{5}+\varepsilon_{5},
\end{gathered}
$$

Where $x=\left(x_{1}, \ldots, x_{k}\right)^{\prime}$ is the vector of explanatory variables, which in our models is the same for each dependent variable, although it could be different; $\beta_{j}=$ $\left(\beta_{j 1}, \ldots, \beta_{j k}\right)^{\prime}, j=1, \ldots, 5$ are the parameter vectors associated with the explanatory variables; and $\varepsilon_{j}, j=1, \ldots, 5$ are random errors that are normally distributed and correlated between themselves. ${ }^{3}$

In practice, the level of trust $Y_{j}^{*}$ cannot be measured as a continuous variable. This is because individuals are asked to locate themselves on a subjective scale of 1 to 10 , meaning that methods for estimating the parameters for the model defined in (1), which are based on an understanding that the distribution of the dependent variables is multivariate normal, are no longer optimal. In this sense, we opt to

\footnotetext{
${ }^{2}$ In the annex, Table 4 with the descriptive analysis of explanatory variables in the multivariate model and Table 5 with the descriptive analysis of explained variables in the multivariate model have been added.

${ }^{3}$ ' Indicates the transpose of the vector
} 
simplify the problem to a model with binary dependent variables based on whether an individual trusts or does not trust.

Let $Y_{j}, j=1, \ldots, 5$, be the measured levels of trust, so that:

$Y_{j}=\left\{\begin{array}{l}\geq 5 \text { if } Y_{j}^{*}>0 \\ <5 \text { if } Y_{j}^{*} \leq 0\end{array}, j=1, \ldots, 5\right.$

In addition, assuming that an individual trusts in something if they indicate a level of trust of 5 or more on the scale of 1 to 10 , the following binary variables are defined:

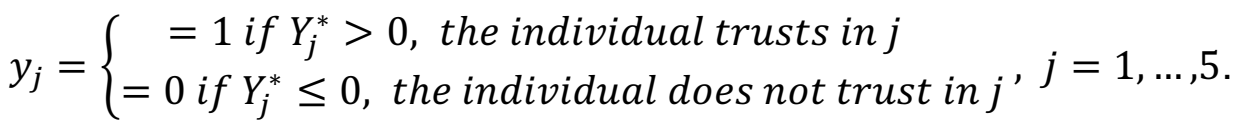

Finally, we model the joint probability that an individual trusts in the 5 items under analysis. This is known as a multivariate Probit model and in this case it is expressed as follows:

$$
\begin{gathered}
P\left(y_{1}=1, y_{2}=1, y_{3}=1, y_{4}=1, y_{5}=1\right) \\
=P\left(Y_{1}^{*}>0, Y_{2}^{*}>0, Y_{3}^{*}>0, Y_{4}^{*}>0, Y_{5}^{*}>0\right) \\
=P\left(x^{\prime} \beta_{1}+\varepsilon_{1}>0, x^{\prime} \beta_{2}+\varepsilon_{2}>0, x^{\prime} \beta_{3}+\varepsilon_{3}>0, x^{\prime} \beta_{4}+\varepsilon_{4}>0, x^{\prime} \beta_{5}+\varepsilon_{5}>0\right) \\
=P\left(\varepsilon_{1} \leq x^{\prime} \beta_{1}, \varepsilon_{2} \leq x^{\prime} \beta_{2}, \varepsilon_{3} \leq x^{\prime} \beta_{3}, \varepsilon_{4} \leq x^{\prime} \beta_{4}, \varepsilon_{5} \leq x^{\prime} \beta_{5}\right) \\
=\Phi_{5}\left(x^{\prime} \beta_{1}, x^{\prime} \beta_{2}, x^{\prime} \beta_{3}, x^{\prime} \beta_{4}, x^{\prime} \beta_{5} ; R\right),
\end{gathered}
$$

where $\Phi_{5}(\cdot ; R)$ is the function of cumulative probability of a multivariate normal curve (dimension 5), with a correlation matrix ${ }^{4} R$.

\footnotetext{
${ }^{4}$ When the variables are standard normal variable, the matrix of variances and covariances are equivalent to the matrix of linear correlations.
} 
We estimate the parameter vectors $\beta_{j}=\left(\beta_{j 1}, \ldots, \beta_{j k}\right)^{\prime}, j=1, \ldots, 5$, by maximising the logarithm of the model's plausibility function (2). Calculating and maximising the logarithm of the plausibility function is more complex than for univariate Probit or Logit models.

We interpret the estimated parameters $\hat{\beta}_{j}=\left(\hat{\beta}_{j 1}, \ldots, \hat{\beta}_{j k}\right)^{\prime}, j=1, \ldots, 5$ in the same way we would if dealing with 5 univariate and independent Probit or Logit models.

\section{Results}

Table 2 shows the variation in the indicators between 2004 and 2012 according to different types of trust ${ }^{5}$. In analysing the data, first we look at how the crisis altered the influence of economic variables on social trust and trust in institutions. Second, we analyse the explanatory capacity of the most significant control variables in the two time periods.

\footnotetext{
${ }^{5}$ The estimated correlation matrix, $\widehat{R}$, provides information on the dependency between levels of trust not captured by the explanatory variables. If these correlations were zero, the optimal result would be to estimate five univariate Probit models. However, the estimated correlations are significantly different to zero.
} 
Table 2

Relationship between different variables and interpersonal and institutional truth in Spain 2004 y 2012 (Seemingly Unrelated Regression Coefficients)

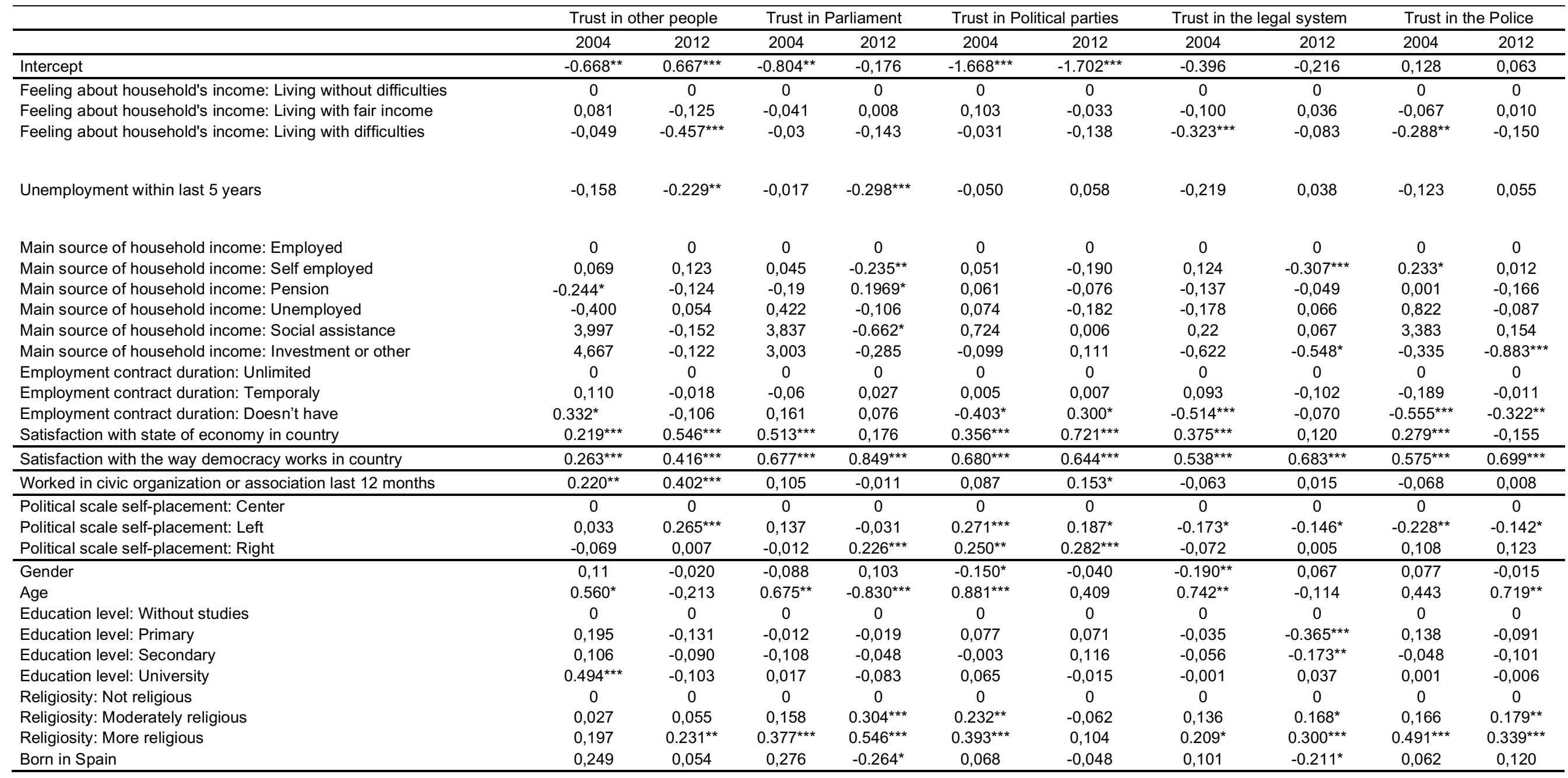

Source: European Social Survey (second and fifth waves).

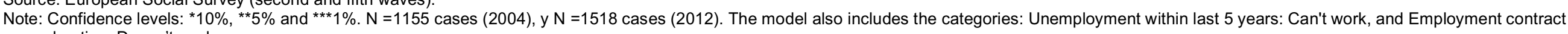
duration: Doesn't apply. 
In today's postmodernity or late modernity, we see increasing evidence of a socalled 'two-thirds society'. That is to say, one part of the population is integrated in the socioeconomic system and the rest are excluded from it (Lash and Urry, 1994). Analysis of our statistical model suggests that the behaviour of these two societal groups - one that is part of the system and one that is increasingly excluded - is increasingly different in terms of social trust and trust in institutions.

On the one hand, the crisis very clearly affected social trust among people with few economic resources. Specifically, people that suffered the most through the crisis stopped trusting in others. Before the crisis, people in financial difficulty and people in financial comfort demonstrated similar levels of trust in other individuals, while after the crisis the two groups reported significantly different levels.

Figure 1 shows the probability of trusting others according to age for individuals who declare that they live with difficulty (thicker lines) and those who live without difficulty (thinner lines). 


\section{Figure 1}

\section{Trust in other people}

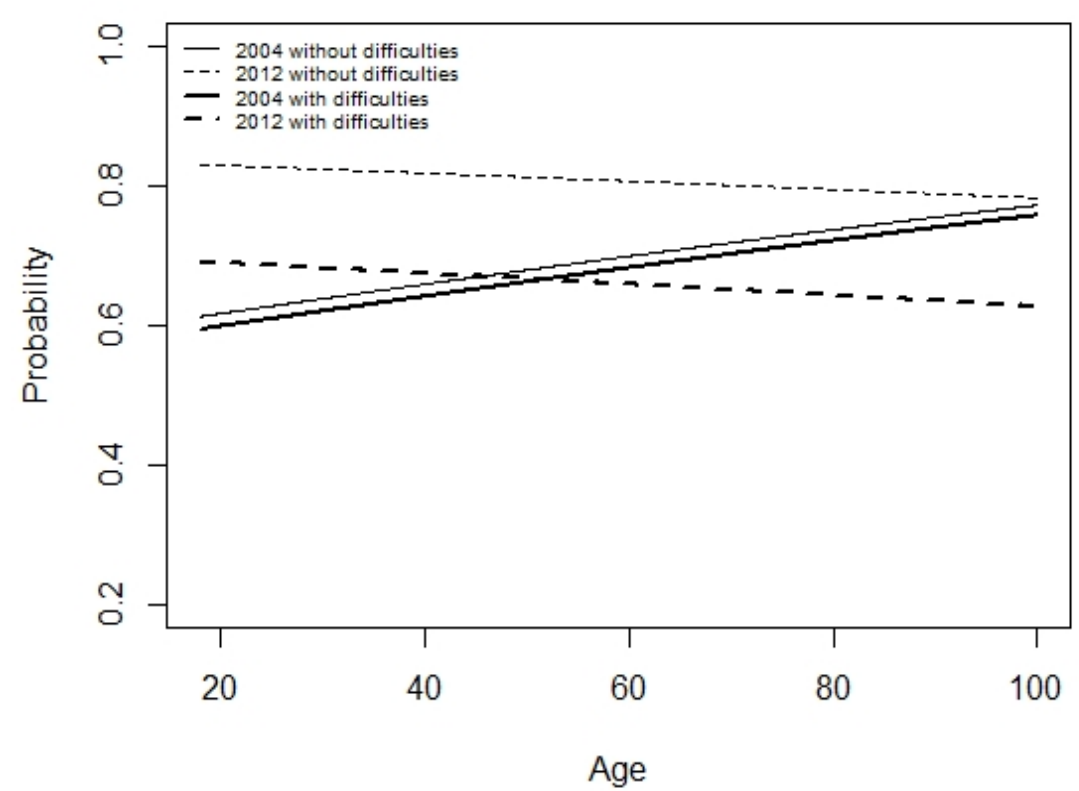

In Table 3 it has been calculated how the joint probability of trusting in the 5 dependent variables (the four institutional trust and the social trust) changes from the year 2004 to 2012 depending on whether the respondent lives with or without difficulties. The general probability of trusting goes from $19.7 \%$ in 2004 to $11.2 \%$ in 2012 , which represents a decrease of approximately $43 \%$. But this decrease in general confidence is explained more by the loss of confidence among those who live with economic difficulties (with a decrease of $49.7 \%$ ) than among those who live without economic difficulties (with a decrease of $41.4 \%$ ). 


\section{Table 3}

\section{Joint probability of trusting in the 5 dependent variables depending on}

whether the respondent lives with or without difficulties

\begin{tabular}{l|rrr|} 
Profile & 2004 & 2012 & Increase \\
\hline Without difficulties & $20.6 \%$ & $12.1 \%$ & $-41.4 \%$ \\
With difficulties & $16.6 \%$ & $8.4 \%$ & $-49.7 \%$ \\
\hline Increase & $-19.2 \%$ & $-30.6 \%$ & \\
\hline \hline General & $19.7 \%$ & $11.2 \%$ & $-43.3 \%$ \\
\hline
\end{tabular}

The hypothesis that people who suffered the most from the crisis lost trust in others is reinforced if we analyse unemployment. In 2004 , social trust among people that had been unemployed once was no different to social trust among people that had never been unemployed. However, this changed in 2013, when unemployed people, or those who had been unemployed at some point, trusted less in others. On the other hand, people who were satisfied with the state of the economy during the crisis - an elite of only $6 \%$ of the population (ESS6 2013) - still trusted more in others than before the crisis.

Trust in political institutions collapsed in much the same way across different economic strata with the arrival of the economic crisis. However, around the time of the crisis, groups from different economic realities began to demonstrate trust or mistrust in institutions based on whether they perceived the behaviour of these institutions to be favourable or unfavourable to their interests. We observe this effect among unemployed people and people who depend on social assistance, who trusted less in parliament than others after the crisis. Self-employed workers also demonstrated interesting changes in trust: during the crisis, such workers lost trust in parliament and in the legal system much like salaried workers. Similarly, individuals 
living off investments and/or rents lost trust in the legal system and in the police during the crisis. Finally, the previously mentioned $6 \%$ of Spanish people satisfied with the economy demonstrated much greater trust in political parties than all other Spaniards.

Civic participation in Spain increased four percentage points during the crisis, from $18 \%$ in 2004 to $22 \%$ of the population in 2013 (ESS2 2005; ESS6 2013). We identify a positive relationship between working in a tertiary sector association and trusting in others, which intensified with the economic crisis. However, levels of trust in institutions did not differ significantly between individuals who participated in civic associations and those who did not, neither before nor during the crisis. We only observe greater levels of trust in political parties among people who worked in tertiary sector associations in the year 2013 , although this data is only marginally significant and is surely explained by the links between some of these associations and the political parties themselves.

In order to analyse the effects of trust in democracy on social trust and trust in institutions, we must bear in mind that the percentage of people satisfied with democracy in Spain dropped dramatically during the crisis. We observe the emergence of a critical citizenry through the fact that in 2004, two in every three individuals positively evaluated the country's democracy, and in 2013 this figure was down to one in every four (ESS2 2005; ESS6 2013). Individuals satisfied with how Spain's democracy was functioning - both before and during the crisis - trusted more in others than individuals who were not satisfied with it. For the group that continued to trust in how democracy was functioning despite the crisis, the crisis had 
the effect of reinforcing this relationship between trust in democracy and social trust. The same is true for trust in institutions: individuals who positively evaluated the functioning of democracy trusted more in all democratic institutions than those who were critical of how democracy was functioning. And, much like the case of social trust, the crisis reinforced this relationship among the minority that continued to trust despite the crisis.

In terms of self-positioning on the political spectrum, the crisis clearly affected individuals placing themselves to the left of the scale, who reported greater levels of social trust than individuals who placed themselves in the centre or on the right. It is interesting to note that the positive relationship between being on the left and trusting others was only significant during the crisis. In the year 2004 , before the crisis, it was not. The relationship between placing oneself to the left of the scale and trusting more in others could be due to the emergence of social mobilization that gradually organized into new left-wing political parties. The fact that the crisis also affected trust in institutions among individuals that placed themselves on the left, who trust less in institutions than those in the centre or on the right, reinforces this possibility.

\section{Conclusions}

This study confirms the hypothesis that, at a time of economic crisis, economic variables had greater influence on levels of social trust and trust in institutions. As posited by Delhey and Newton (2005), Rothstein and Uslaner (2005) and Nannestad (2008), this is due to the fact that trust is associated with equality of economic 
conditions and opportunities. The explanatory capacity of economic factors in understanding social trust and trust in institutions is enhanced mainly as a result of increased inequality. The data analysis conducted here indicates that increases in socioeconomic difficulty and inequality, stemming from the economic crisis, had a double effect: among social groups that suffered the worst effects of the crisis - the unemployed, or those in financial difficulty - trust in other individuals and in institutions decreased, while it increased among groups that were satisfied with the economy despite the crisis. Therefore, we can state that inequality increases the social distance between individuals as argued by Fairbrother and Martin (2013), that trust is reinforced among groups with upward social mobility, and the inverse (Yaojun, Savage and Warde, 2008), and, finally, that situations of socioeconomic difficulty, such as unemployment, are associated with a decrease in trust (Iravany and Dindar, 2011).

One could argue that performance theory, which states that trust in institutions depends on the extent to which they function well, is useful in explaining decreased trust in political institutions among the Spanish people during the economic crisis. However, our statistical analysis suggests that the Spanish case reflects more closely the theory of Lipset and Schneider (1987), who stress that levels of trust in institutions primarily depend on the influence that the actions of those institutions have on people's economic wellbeing. It is true that in the Spanish case, levels of trust decreased overall, but a detailed analysis suggests that some important interest groups - the unemployed, uncontracted workers, individuals dependent on social assistance, self-employed workers, landlords, and investors - behave differently to 
other groups in that their trust or mistrust in institutions depends on whether they perceive those institutions to benefit them economically, or not.

Although the capacity of economic factors to explain social trust and trust in institutions increases at times of economic crisis due mainly to increased inequality, the explanatory variables from social capital theory - levels of civic participation and perceptions of how democracy is functioning - continue to be important and highly significant, although their explanatory capacity is also influenced by the effects of the crisis. In that regard, our study notes that there is a significant relationship between civic participation and social trust, as demonstrated by well-known studies (Putnam, 1993; Brehm and Rahn, 1997). However, the relationship between civic participation and trust in institutions is not significant, as suggested by the results of studies by Newton $(1999,2001)$ and Newton and Norris (2000). Our analysis also confirms the relationship between satisfaction with democracy and both social trust and trust in institutions, as posited by Zmerli and Newton (2008). Moreover, economic crisis reinforces this relationship.

Finally, authors such as Putnam (1993) and Fukuyama (1995) argue that an increasingly unequal distribution of income and wealth generates a general decrease in trust. However, when analysing the effects of the 2008 economic crisis in the Spanish case at a global level, we observe a notable decrease in trust in institutions together with a slight increase in social trust: the two types of trust do not behave in a mutually supportive manner. This may be due to the effect that the economic crisis had in terms of increasing inequalities. Spain, of all OECD countries, experienced the greatest increase in inequality from the outset of the crisis: almost 10 times more 
than the European average. The economic crisis was particularly harsh on the poorest social groups, which exacerbated the two-thirds society phenomenon. The opinions of groups that were socially excluded and suffered the highest levels of poverty, inequality and marginalisation as a result of the crisis increasingly differed from others, and particularly from the economic and social elite. A general process of attitude polarisation took place, where personal economic situation played an important role. However, this phenomenon would be expected to drag levels of social trust down rather than pushing them up, suggesting that there were other factors at play.

One plausible explanation of why social trust and trust in institutions were not mutually supportive during the economic crisis in Spain relates to the emergence of social movements (such as the Movimiento $15 \mathrm{M}$ ), which gradually organized into new left-wing political parties. The appearance of a new leftist sentiment that was more critical of traditional political institutions but allowed for greater trust in individuals, the creation of community responses focused on social transformation and a new way of conceiving of and engaging in a collective action, could explain why social trust did not suffer to the extent that trust in institutions did during the crisis. Our data indicate that, during the period of the crisis, those who placed themselves on the left of the political spectrum changed their way of thinking. From that moment onwards, they demonstrated more trust in other individuals and less trust in institutions than groups who placed themselves in the centre or on the right of the political spectrum. Future research should further explore this phenomenon and assess whether this effect persists when the economy begins to improve. 


\section{Bibliography}

Armingeon, Klaus, Kay Guthmann and David Weisstanner (2016). "How the Euro divides the union: the effect of economic adjustment on support for democracy in Europe". Socioeconomic Review 14 (1): 1-26.

Banco de España (2013). Boletín económico. Madrid: Banco de España.

Blanco, Ismael, Sonia Fleury and Joan Subirats (2012). "Nuevas miradas sobre viejos problemas: Periferias urbanas y transformación social", Gestión y política pública 21: 3-40.

Brehm, John and Wendy Rahn (1997). "Individual Level Evidence for the Causes and Consequences of Social Capital", American Journal of Political Science 41(3): 999-1023.

Buskens, Vincent (1998). "The social structure of trust”. Social Networks 20 (3): 265 $-289$.

Cullen-Lester, Kristin L. and Francis J. Yammarino (2016) "Collective and network approaches to leadership: special issue introduction". Leadership Quarterly 27 (2): 173-180.

Delhey, Jan and Kenneth Newton (2005). "Predicting cross-national levels of social trust: Global pattern or Nordic exceptionalism? "European Sociological Review 21(4): 311-327.

Della Porta, Donatella (2015). Social movements in times of austerity: bringing capitalism back into protest analysis. Cambridge: John Wiley and Sons.

Eurostat (2015). GDP per capita in PPS. Brussels: European Commission.

Fairbrother, Malcolm and Isaac W. Martin (2013). "Does inequality erode social trust? Results from multilevel models of US states and countries". Social Science Research 42: 347-360.

Fukuyama, Francis (1995), The Social Virtues and the Creation of Prosperity. Nueva York: Free Press.

Hearn, Frank (1997), Moral Order and Social Disorder: The American Search for Civil Society. Nueva York: Aldine de Gruyter.

Inglehart, Ronald (1997). Modernization and Postmodernization. Princeton, NJ: Princeton University Press.

Instituto Nacional de Estadística (INE) (2013). Encuesta de la población active (EPA). Madrid: INE.

Instituto Nacional de Estadística (INE) (2015). Encuesta de condiciones de vida (ECV). Madrid: INE.

Intermon-Oxfam (2016). Una economía al servicio del 1\%. La situación en España. www.oxfamintermon.org

Jagodzinski, Wolfgang and Kazufumi Manabe (2004). "How to Measure Interpersonal Trust? A Comparison of Two Different Measures." ZA Information 55: 85-97. 
Kramer, Gerald H. (1983). “The Ecological Fallacy Revisited: Aggregate- versus Individual-Level Findings on Economics and Elections, and Sociotropic Voting". American Political Science Review 77: 92-111.

Lash, Scott and John Urry (1994) The Economy of Signs and Spaces. London: Sage.

Leighley, Jan E. (1996). "Group membership and the Mobilization of Political Participation". Journal of Politics 58 (2): 447-463.

Levi, Margaret and Laura Stoker (2000). "Political Trust and Trustworthiness." Annual Review of Political Science 3: 475-508.

Lipset, Seymour M., and William Schneider (1987). The Confidence Gap. Baltimore; Johns Hopkins University Press.

Luhmann, Niklas (1979). Trust and Power. London: Pitman.

Molm, Linda D., Nobuyuki Takahashi and Gretchen Peterson (2000). "Risk and trust in social exchange: An experimental test of a classical proposition". American Journal of Sociology 105 (5): 1396-1427.

Montero, José R., Sonja Zmerli and Ken Newton (2008): "Confianza social, confianza política y satisfacción con la democracia" Revista Española de Investigaciones Sociológicas, 122: 11-54.

Mouffe, Chantal (1992). Democratic citizenship and the political community. Dimensions of radical democracy: Pluralism, citizenship, community. London: Routledge.

Nannestad, Peter (2008). "What have we learned about generalized trust, if anything?" Annual Review of Political Science 11: 413-436.

Newton, Kenneth (1999). "Social and Political Trust in Established Democracies." In Pippa Norris (ed.) Critical Citizens. Global Support for Democratic Government. Oxford: Oxford University Press.

Newton, Kenneth (2001). "Trust, social capital, civil society, and democracy". International Political Science Review 22 (2): 201-214.

Newton, Kenneth and Pippa Norris (2000). "Confidence in Public Institutions: Faith, Culture, or Performance?" In Pharr S. and Putnam R. (eds.) Disaffected Democracies: What's Troubling the Trilateral Countries? Princeton, NJ: Princeton University Press.

Norris, Pippa (2011) Democratic Deficit: Critical Citizens Revisited. Cambridge: Cambridge University Press.

OECD (2014). Income Inequality and Poverty. Paris: OECD.

Parés, Marc, Sonia Ospina and Joan Subirats (eds.) (2017). Social Innovation and Democratic Leadership: Communities and Social Change from Below.

Cheltenham: Edward Elgar Publishing.

Putnam, Robert (1993). Making Democracy Work: Civic Traditions in Modern Italy. Princeton, NJ: Princeton University Press.

Putnam, Robert (2000). Bowling Alone: The Collapse and Revival of American Community. New York: Simon and Schuster. 
Rahn, Wendy M. and John E. Transue, (1998), "Social trust and value change: The decline of social capital in American youth, 1976-1995". Political Psychology 19 (3): $545-565$.

Rosenstone, Steven J. and John M. Hansen (1993). Mobilization, Participation, and Democracy in America. New York: Macmillan.

Rothstein, Bo and Eric M. Uslaner (2005). "All for all: Equality, corruption, and social trust". World Politics vol. 58 (1): 41-72.

Sønderskov, Kim Mannemar, and Peter Thisted Dinesen (2016). "Trusting the State, trusting each other? The effect of institutional trust on social trust." Political Behavior 38 (1): 179-202.

Torcal, Mariano (2014) "The Decline of Political Trust in Spain and Portugal: Economic Performance or Political Responsiveness". American Behavioral Scientist 58 (12): 1542-1567.

Uslaner, Eric M. (2002). The moral foundations of trust. Cambridge, UK: Cambridge University Press.

Yamagishi, Toshio (2001). "Trust as a Form of Social Inteligence" in Cook K. S., Trust in Society, vol 2. The Russell Sage Foundation.

Yaojun Li, Mike Savage, and Alan Warde (2008). "Social mobility and social capital in contemporary Britain". The British Journal of Sociology 59 (3): 391-411.

Zmerli, Sonja and Ken Newton (2008). "Social trust and attitudes toward democracy". Public Opinion Quarterly 72: 706-724.

Zmerli, Sonja and Juan C. Castillo (2015). "Income inequality, distributive fairness and political trust in Latin America". Social Science Research 52: 179-192. 


\section{Annex}

\section{Table 4}

\section{Descriptive analysis of explanatory variables in the multivariate model}

\begin{tabular}{|c|c|c|c|c|}
\hline & \multicolumn{2}{|c|}{2004} & \multicolumn{2}{|c|}{2012} \\
\hline & Mean & STD & Mean & STD \\
\hline Feeling about household's income: Living without difficulties ${ }^{* * *}$ & 0.392 & 0.490 & 0.267 & 0.443 \\
\hline Feeling about household's income: Living with fair income & 0.454 & 0.499 & 0.440 & 0.497 \\
\hline Feeling about household's income: Living with difficulties*** & 0.154 & 0.362 & 0.293 & 0.456 \\
\hline Unemployment within last 5 years ${ }^{\star * *}$ & 0.136 & 0.344 & 0.238 & 0.426 \\
\hline Main source of household income: Employed ${ }^{* * *}$ & 0.649 & 0.479 & 0.554 & 0.498 \\
\hline Main source of household income: Self employed & 0.153 & 0.361 & 0.140 & 0.347 \\
\hline Main source of household income: Pension ${ }^{\star *}$ & 0.185 & 0.389 & 0.220 & 0.414 \\
\hline Main source of household income: Unemployed ${ }^{* \star \star \star x}$ & 0.009 & 0.093 & 0.054 & 0.227 \\
\hline Main source of household income: Social assistance ${ }^{* * *}$ & 0.001 & 0.034 & 0.017 & 0.128 \\
\hline Main source of household income: Investment or other & 0.004 & 0.060 & 0.015 & 0.122 \\
\hline Employment contract duration: Unlimited & 0.465 & 0.500 & 0.477 & 0.500 \\
\hline Employment contract duration: Temporaly & 0.191 & 0.395 & 0.180 & 0.385 \\
\hline Employment contract duration: Doesn't have & 0.050 & 0.219 & 0.053 & 0.225 \\
\hline Satisfaction with state of economy in country ${ }^{* * *}$ & 0.475 & 0.501 & 0.060 & 0.237 \\
\hline Satisfaction with the way democracy works in country & 0.661 & 0.475 & 0.261 & 0.440 \\
\hline Worked in civic organization or association last 12 months s.* $^{\star \star *}$ & 0.197 & 0.399 & 0.245 & 0.431 \\
\hline Gender ( $1=$ Men, $0=$ Women) & 0.531 & 0.501 & 0.509 & 0.500 \\
\hline $\mathrm{Age}^{\star * *}$ & 43.110 & 17.580 & 46.746 & 17.227 \\
\hline Education level: Without studies & 0.182 & 0.387 & 0.103 & 0.304 \\
\hline Education level: Primary & 0.151 & 0.359 & 0.161 & 0.368 \\
\hline Education level: Secondary ${ }^{* * *}$ & 0.449 & 0.499 & 0.309 & 0.463 \\
\hline Education level: University ${ }^{* \star *}$ & 0.218 & 0.414 & 0.173 & 0.379 \\
\hline Religiosity. Not religious ${ }^{\star *}$ & 0.156 & 0.364 & 0.188 & 0.391 \\
\hline Religiosity. Moderately religious ${ }^{\star * *}$ & 0.520 & 0.501 & 0.460 & 0.499 \\
\hline Religiosity. More religious* & 0.324 & 0.470 & 0.352 & 0.478 \\
\hline Born in Spain ${ }^{* \star \star t}$ & 0.943 & 0.233 & 0.899 & 0.302 \\
\hline Political scale self-placement: Center ${ }^{* \star \star}$ & 0.481 & 0.501 & 0.398 & 0.490 \\
\hline Political scale self-placement: Left ${ }^{\star \star \star}$ & 0.283 & 0.452 & 0.343 & 0.475 \\
\hline Political scale self-placement: Right ${ }^{\star}$ & 0.236 & 0.426 & 0.259 & 0.439 \\
\hline
\end{tabular}

Confidence levels: ${ }^{*} 10 \%,{ }^{*} 5 \%$ and ${ }^{m *} 1 \%$ 
Table 5

Descriptive analysis of explained variables in the multivariate model

\begin{tabular}{|c|c|c|c|c|}
\hline & \multicolumn{2}{|c|}{2004} & \multicolumn{2}{|c|}{2012} \\
\hline & Mean & STD & Mean & STD \\
\hline Most people can be trusted or you can't be too careful & 5.054 & 2.177 & 5.202 & 2.101 \\
\hline Trust in country's parliament & 5.207 & 2.198 & 3.445 & 2.522 \\
\hline Trust in political parties & 3.826 & 2.273 & 1.893 & 2.198 \\
\hline Trust in the legal system & 4.806 & 2.381 & 3.624 & 2.569 \\
\hline Trust in the police & 5.926 & 2.266 & 5.854 & 2.437 \\
\hline
\end{tabular}

